Bond University

Research Repository

\title{
Assessing the expected current and future competencies of quantity surveyors in the Malaysian built environment
}

Yap, Jeffrey Boon Hui; Skitmore, Martin; Lim, Yi Wen; Loo, Siaw Chuing; Gray, Jason

Published in:

Engineering, Construction and Architectural Management

DOI:

10.1108/ECAM-01-2021-0091

Licence:

CC BY-NC

Link to output in Bond University research repository.

Recommended citation(APA):

Yap, J. B. H., Skitmore, M., Lim, Y. W., Loo, S. C., \& Gray, J. (2022). Assessing the expected current and future competencies of quantity surveyors in the Malaysian built environment. Engineering, Construction and Architectural Management, 29(6), 2415-2436. https://doi.org/10.1108/ECAM-01-2021-0091

\section{General rights}

Copyright and moral rights for the publications made accessible in the public portal are retained by the authors and/or other copyright owners and it is a condition of accessing publications that users recognise and abide by the legal requirements associated with these rights.

For more information, or if you believe that this document breaches copyright, please contact the Bond University research repository coordinator. 


\title{
Assessing the expected current and future competencies of quantity surveyors in the Malaysian built environment
}

\author{
Jeffrey Boon Hui Yapa ${ }^{a}$, Martin Skitmore ${ }^{b}$, Yi Wen Limc, Siaw Chuing \\ Loo $^{\mathrm{d}}$, Jason Gray \\ a Associate Professor, Department of Surveying, Lee Kong Chian Faculty of Engineering \\ and Science, Universiti Tunku Abdul Rahman (UTAR), Kajang, Malaysia
}

Email: bhyap@utar.edu.my (correspondingauthor)

${ }^{b}$ University Professorial Fellow of Quantity Surveying and Construction Management, Faculty of Society and Design, Bond University, Australia

Email:mskitmor@bond.edu.au

${ }^{c}$ Graduate, Department of Surveying, Lee Kong Chian Faculty of Engineering and Science, Universiti Tunku Abdul Rahman (UTAR), Kajang, Malaysia

Email:yiwenlim97@gmail.com

${ }^{d}$ Senior Lecturer, Centre of Building, Construction and Tropical Architecture, Faculty of Built Environment, University of Malaya, Kuala Lumpur, Malaysia

Email: siawchuing@um.edu.my

${ }^{e}$ Lecturer, School of Built Environment, Science and Engineering Faculty, Queensland University of Technology (QUT), Brisbane, Australia

Email:jm.gray@qut.edu.au

\section{Disclosure statement}

No potential conflict of interest was reported by the authors.

This is the peer reviewed version of the following article: Yap, J. B. H., Skitmore, M., Lim, Y. W., Loo, S. C., \& Gray, J. (Accepted/In press). Assessing the expected current and future competencies of quantity surveyors in the Malaysian built environment. Engineering, Construction and Architectural Management. https://doi.org/10.1108/ECAM-01-2021-0091.

This author accepted manuscript is deposited under a Creative Commons Attribution Non-commercial 4.0 International (CC BY-NC) licence. This means that anyone may distribute, adapt, and build upon the work for non-commercial purposes, subject to full attribution. If you wish to use this manuscript for commercial purposes, please contact 


\section{Acknowledgements}

Special thanks go to all survey participants. The authors are grateful to the anonymous reviewers for their valuable comments and inputs during the review process of this paper.

This is the peer reviewed version of the following article: Yap, J. B. H., Skitmore, M., Lim, Y. W., Loo, S. C., \& Gray, J. (Accepted/In press). Assessing the expected current and future competencies of quantity surveyors in the Malaysian built environment. Engineering, Construction and Architectural Management. https://doi.org/10.1108/ECAM-01-2021-0091.

This author accepted manuscript is deposited under a Creative Commons Attribution Non-commercial 4.0 International (CC BY-NC) licence. This means that anyone may distribute, adapt, and build upon the work for non-commercial purposes, subject to full attribution. If you wish to use this manuscript for commercial purposes, please contact 


\title{
Assessing the expected current and future competencies of quantity
}

\section{surveyors in the Malaysian built environment}

\begin{abstract}
Purpose - Quantity surveying is a profession that blends engineering, construction and economics. To be competent is to have the ability to apply the set of related knowledge, skills and abilities to perform a task effectively. This paper examines the competency requirements for quantity surveyors (QSs) in the face of changing and increasing client needs.

Design/methodology/approach - Based on a detailed meta-analysis of the literature, 12 basic/core and 16 evolving competencies are identified. Primary data were gathered through a field survey involving practicing QSs from client, consultant and contractor organisations, and university students undertaking QS programmes in Malaysia. The data obtained were analysed using both descriptive and inferential statistical tools.
\end{abstract}

Findings - The significance of the basic/core and evolving competencies are presented. Overall, the most important contemporary skills are cost planning, valuation of works, measurement/quantification and contract documentation. The evolved roles require expertise in communication and negotiation, ethics and professional conduct and value management. The analysis of variance (ANOVA) indicates there are misaligned expectations of the proficiency levels needed to provide contemporary and future services between practitioners in client/consultant organisations, contractors and new generation students.

Originality/value - The findings provide guidance on the education, training and practice of quantity surveying to deal with emerging challenges in the dynamic built environments in Malaysia and beyond.

\section{Keywords:}

Competencies, skills, quantity surveyor (QS), construction industry, Malaysia 


\section{Introduction}

"Quantity surveyors are the cost managers of construction ... work in all sectors of the construction industry worldwide."

(RICS, 2018, p. 6)

As construction needs and jobs are growing steadily around the world, an increasing number of skilled roles are becoming available, especially in such positions as quantity surveyors ${ }^{1}$ (QSs), with expert knowledge of construction costs and contracts. Thus, this profession adds value in the financial, contractual and commercial aspects of construction projects in all stages, from conception to construction and post-construction (Ramdav and Harinarain, 2020; Yogeshwaran et al., 2018). Nkado and Meyer (2001, p. 481) note that QSs can only “contribute to overall construction project performance by acquiring, developing and deploying appropriate competencies". QS core competencies include estimating construction costs, quantification, preparing contract documentation (such as tendering documents and cost planning documents), managing contracts and formulating final accounts (Shafiei and Said, 2008). Despite the importance of technical competencies in professional QS services, higher levels of management-oriented competencies are expected for future services in a dynamic built environment (Nkado and Meyer, 2001). For example, an effective procurement manager needs both technical and tactical skills (Oke et al., 2018). As highlighted by Adesi, OwusuManu and Murphy (2018), the strategic competences for professional QS services have not been constructively appraised. It is worth noting that some important areas of competencies are

\footnotetext{
${ }^{1}$ Equivalently referred to as cost consultants or cost engineers. Following the usual convention in
} practice, the abbreviation QS is also used here to denote the term quantity surveying.

This is the peer reviewed version of the following article: Yap, J. B. H., Skitmore, M., Lim, Y. W., Loo, S. C., \& Gray, J. (Accepted/In press). Assessing the expected current and future competencies of quantity surveyors in the Malaysian built environment. Engineering, Construction and Architectural Management. https://doi.org/10.1108/ECAM-01-2021-0091. This author accepted manuscript is deposited under a Creative Commons Attribution Non-commercial 4.0 International (CC BY-NC) licence. This means that anyone may distribute, adapt, and build upon the work for non-commercial purposes, subject to full attribution. If you wish to use this manuscript for commercial purposes, please contact permissions@emerald.com. 
currently not exhibited by QSs (Oke et al., 2019). In investigating the competencies of graduate QS in Sri Lanka, Yogeshwaran, Perera and Ariyachandra (2018) reported that the majority of competencies are below the industry expectations. For this reason, QSs are not providing or meeting current market expectations, particularly in emerging markets such as Malaysia (Olanrewaju, 2016).

As highlighted by Wao (2016), there will be future growth in the roles of QSs over the next 10-15 years, especially in areas such as information technology and sustainable construction. Likewise, Ashworth, Hogg and Higgs (2013) opine that the future development of QS services is likely to be influenced by: client focus, new application of information and communication technology (ICT), research and sustainability agenda. Due to the need for appropriate skills and competencies, the profession is regularly confronted with challenges and opportunities in new markets (Dada and Jagboro, 2012). Ramdav and Harinarain (2020), for instance, find the major challenges facing the profession in South Africa to be predominantly overcoming an inability to undertake new roles beyond core QS services, and lack of relevant QS expertise in the upcoming generation of professionals. These are closely associated with such QS technical inadequacies as resistance to change and lack of knowledge of, and about, the profession. In Nigeria, the three dimensions of competence are relating to procurement and value management, commercial management, and communication and entrepreneuship (Dada, 2017). In this light, the competence of QSs are affected by organisational structure and team development, industrial exposure, and educational training (Dada and Musa, 2016). The strategic competences for pricing QS consultancy services are significantly related to the managerial and professional competence of QS consultants (Adesi et al., 2018). To remain competitive, professional QSs need to adapt themselves to undertake new roles built upon their core competencies in traditional functions to meet changing client needs (Chong et al., 2012). This will then serve as the foundation for education, training and continuing professional

\footnotetext{
This is the peer reviewed version of the following article: Yap, J. B. H., Skitmore, M., Lim, Y. W., Loo, S. C., \& Gray, J. (Accepted/In press). Assessing the expected current and future competencies of quantity surveyors in the Malaysian built environment. Engineering, Construction and Architectural Management. https://doi.org/10.1108/ECAM-01-2021-0091. This author accepted manuscript is deposited under a Creative Commons Attribution Non-commercial 4.0 International (CC BY-NC) licence. This means that anyone may distribute, adapt, and build upon the work for non-commercial purposes, subject to full attribution. If you wish to use this manuscript for commercial purposes, please contact permissions@emerald.com.
} 
development of QSs aspiring to enhancing their quality of services and survival of QS firms operating in highly saturated markets.

This study aims to investigate the expected competencies of QSs in the Malaysian built environment. The specific objectives are to: (1) identify and appraise the basic/core competency requirements for QSs; and (2) examine the critical evolving skills needed to keep up with the changing market.

\section{Expected competencies of QS}

"To be competent is to have the skill or ability to perform a task or function."

(RICS, 2018. p. 5)

Competence refers to the "abilities, skills, and capabilities that a person has in a particular domain" (Buvik and Rolfsen, 2015, p. 1486). Holmes and Joyce (1993) describe competency as an activity, achievement and behaviour an individual needs to perform, or the capability to allocate knowledge and information in different circumstances in the respective occupational field. Meyer and Semark (1996) incorporate personal attributes and value orientation as new elements into this definition. In the context of project management, competence is the "skill and capacity required to complete assigned activities within the project constraints" (Project Management Institute, 2017, p. 319). According to Wao and Flood (2016), competency requirements are mainly utilised to enhance the professionals' performance in respective occupational areas. Drawing from the above, competency is the ability to apply or practise a combined set of associated knowledge, skills, capabilities and personal attributes necessary to successfully achieve "critical work functions" or ultimately result in enhanced employee performance and organisational success. According to Project Management Institute (2017), the key skill sets for effective project managers encompass technical knowledge and behaviours, leadership capabilities, and expertise in strategic and business management. To

\footnotetext{
This is the peer reviewed version of the following article: Yap, J. B. H., Skitmore, M., Lim, Y. W., Loo, S. C., \& Gray, J. (Accepted/In press). Assessing the expected current and future competencies of quantity surveyors in the Malaysian built environment. Engineering, Construction and Architectural Management. https://doi.org/10.1108/ECAM-01-2021-0091. This author accepted manuscript is deposited under a Creative Commons Attribution Non-commercial 4.0 International (CC BY-NC) licence. This means that anyone may distribute, adapt, and build upon the work for non-commercial purposes, subject to full attribution. If you wish to use this manuscript for commercial purposes, please contact permissions@emerald.com.
} 
this end, the successful delivery of a construction project involves the four fundamental elements of comprehension, competence, commitment and communication (Toor and Ogunlana, 2008).

The competencies expected of QSs comprise three distinct categories, namely: mandatory (personal, interpersonal, professional practice and business skills), technical core (primary skills) and technical optional (additional skill requirements) (RICS, 2018). The skill base for the profession includes management, documentation, analysis, appraisal, quantification, synthesis and communication (Ashworth et al., 2013). In classifying the skills required of QSs, Dada and Jagboro (2012) divide these into basic (essential supporting skills) and core (skills germane to the common duties of QSs) competencies. The strengths of the profession are problem-solving abilities, measuring skills, project viability and interpersonal skills (Ramdav and Harinarain, 2020). The knowledge base is associated with four key areas: technology, information, cultural and economic (Ashworth et al., 2013). Given that the construction industry has evolved to become increasingly vital and mature, with client demands quickly rising and becoming more complex, there is an increasing need to change the professional role and competency requirements of QSs (Oke et al., 2018). These diversified roles necessitate the rapid evolvement of knowledge and skills for the effective performance of a certain task in and out of the profession (Chandramohan et al., 2020; Ramdav and Harinarain, 2020). Cartlidge (2018, p. 40) elucidates that "QS has repeatedly demonstrated the ability to reinvent itself and adapt to change".

Following a detailed meta-analysis of the literature, Table 1 presents a list of the most commonly cited basic/core and evolving competencies expected of a professional QS. This shows the prevailing professional roles to be cost planning, contract documentation, financial management and general procurement advice, while feasibility studies, reference to construction law/regulations and professional practice are less frequent. On the other hand, the

\footnotetext{
This is the peer reviewed version of the following article: Yap, J. B. H., Skitmore, M., Lim, Y. W., Loo, S. C., \& Gray, J. (Accepted/In press). Assessing the expected current and future competencies of quantity surveyors in the Malaysian built environment. Engineering, Construction and Architectural Management. https://doi.org/10.1108/ECAM-01-2021-0091. This author accepted manuscript is deposited under a Creative Commons Attribution Non-commercial 4.0 International (CC BY-NC) licence. This means that anyone may distribute, adapt, and build upon the work for non-commercial purposes, subject to full attribution. If you wish to use this manuscript for commercial purposes, please contact permissions@emerald.com.
} 
most prevalent evolving roles are project management, life cycle cost analysis and quality assurance.

[Please insert Table 1 here]

\section{Research method}

A questionnaire was designed based on the literature review. In this, Section A requests demographic information of the respondents (e.g. current role and years of working experience in the construction industry); and Section $\mathrm{B}$ and $\mathrm{C}$ request an indication of the level of competency for basic/core skills (A1-A12) and evolving skills (B1-B16) currently expected of a QS, measured on a 5-point Likert scale from 1 ("not significant") to 5 ("very significant").

The target population comprises QS practitioners and university students undertaking QS programmes in Malaysia. The sampling frame consists of representatives from contractors, consultants, clients (developers) and undergraduates. The viewpoints of industry practitioners were obtained as they have direct dealings with QSs on construction projects and/or provide QS services to reflect the industry needs. As for the undergraduates, their responses were used to observe the perspectives of new generation QSs shaped by their training and expectations of the profession. The sample selection was carried out using stratified convenience and snowball techniques. A pilot study with 30 respondents was first conducted to test the comprehensibility and design of the questionnaire prior to its industry-wide distribution. Both sets of competencies had Cronbach's alpha values of above 0.90 - exceeding the 0.70 needed to establish internal consistency between the variables (Hair et al., 2019). As no further modification was made to the pilot study questionnaire, the responses of all the 30 respondents involved were included in the main survey.

In addition to descriptive statistics, univariate and multivariate statistical techniques are used to analyse the data. One-sample $t$-tests with the population mean value set at 3 are used

\footnotetext{
This is the peer reviewed version of the following article: Yap, J. B. H., Skitmore, M., Lim, Y. W., Loo, S. C., \& Gray, J. (Accepted/In press). Assessing the expected current and future competencies of quantity surveyors in the Malaysian built environment. Engineering, Construction and Architectural Management. https://doi.org/10.1108/ECAM-01-2021-0091. This author accepted manuscript is deposited under a Creative Commons Attribution Non-commercial 4.0 International (CC BY-NC) licence. This means that anyone may distribute, adapt, and build upon the work for non-commercial purposes, subject to full attribution. If you wish to use this manuscript for commercial purposes, please contact permissions@emerald.com.
} 
to evaluate competency attributes, where $\mathrm{H}_{0}$ is rejected when $\mathrm{p}<0.05$. In order to determine the level of significance, mean scores were calculated by averaging all scores of the respondents for each competency - a tool which has been widely employed in construction management (Amoatey and Danquah, 2018; Oke and Otasowie, 2020) and competence-related (Dada, 2017; Kwofie et al., 2018) studies. The mean values range from 1 to 5 (extrapolated from the Likert-scale points). Therefore, the closer the mean score of any competency is to 5, the higher level of its significance. If two or more competencies have the same mean value, the one with the lower standard deviation is considered to be more important (Ye et al., 2014). Homogeneity of variances, analysis of variance (ANOVA) and Kruskal-Wallis (KW) tests are used to evaluate the perceived importance of the basic/core and evolving competencies between the different respondent groups of contractors, consultants, clients and students.

\section{Characteristics of respondents}

A total of 300 e-survey forms were distributed using emails and social media platforms (e.g. Facebook, Linkedin) from January to February 2020. 122 valid responses were returned which represents $40.7 \%$ of the total number of questionnaire administered. This exceeds the average survey response rate of $30 \%$ in the construction industry (Yap and Skitmore, 2018) and is considered adequate (Dada, 2017). Furthermore, the sample size satisfies the central limit theorem (Memon et al., 2020).

The characteristics of the respondents are summarised in Table 2, showing that there is an equal distribution between the four categories of respondents. Nearly half the practitioners have over 5 years of working experience in the construction industry, having a good and sufficient knowledge of their profession.

[Please insert Table 2 here]

\footnotetext{
This is the peer reviewed version of the following article: Yap, J. B. H., Skitmore, M., Lim, Y. W., Loo, S. C., \& Gray, J. (Accepted/In press). Assessing the expected current and future competencies of quantity surveyors in the Malaysian built environment. Engineering, Construction and Architectural Management. https://doi.org/10.1108/ECAM-01-2021-0091. This author accepted manuscript is deposited under a Creative Commons Attribution Non-commercial 4.0 International (CC BY-NC) licence. This means that anyone may distribute, adapt, and build upon the work for non-commercial purposes, subject to full attribution. If you wish to use this manuscript for commercial purposes, please contact permissions@emerald.com.
} 


\section{Results}

\section{Analysis of basic/core competencies}

With a Cronbach's alpha value of 0.938 , the reliability of the 12 variables is excellent (Doloi, 2009). The one-sample $t$-test results reveal that all the basic/core competencies (A1-A12) are statistically significant $(p<0.01)$. Table 3a presents the mean scores and standard deviations of the significance ratings for each basic/core competency overall and as viewed by the respondent types. Overall, the mean scores range from 3.566 to 4.541 , with the five most important skills being: cost planning, valuation of works, measurement/quantification, contract documentation and personal/interpersonal skills, with mean scores of 4.541, 4.541, 4.467, 4.467 and 4.303, respectively. Intriguingly, business management, feasibility studies and general procurement advice are ranked lowest.

[Please insert Tables 3a, 3b and 3c here]

Except for 'personal/interpersonal skills', 'cost planning', 'financial management', 'general procurement advice' and 'measurement/quantification', the basic/core competencies are significantly different (see Table $3 b$ ). These differences indicate a different perspective among the respondents, as their role in the project tends to influence how they value the QS skill according to how much the respondent type benefits from this skill. As a high degree of fragmentation is commonplace in construction, professionals tend to operate independently, which often results in inefficiency (Yap and Skitmore, 2018). For instance, the client/consultant and contractor groups often hold extremely different perceptions regarding the significance of various issues affecting the performance of construction projects (Lo et al., 2006). Students' views are also examined, to gauge their expectations, and compared with industry needs. Based on the breakdown of basic/core competencies in Table $3 \mathrm{~b}$, further one-way ANOVA from summary data groups the variables in which four distinct groups are observed (see Table $3 \mathrm{c}$ ).

\footnotetext{
This is the peer reviewed version of the following article: Yap, J. B. H., Skitmore, M., Lim, Y. W., Loo, S. C., \& Gray, J. (Accepted/In press). Assessing the expected current and future competencies of quantity surveyors in the Malaysian built environment. Engineering, Construction and Architectural Management. https://doi.org/10.1108/ECAM-01-2021-0091. This author accepted manuscript is deposited under a Creative Commons Attribution Non-commercial 4.0 International (CC BY-NC) licence. This means that anyone may distribute, adapt,
} 


\section{Analysis of evolving competencies}

Cronbach's coefficient alpha is 0.933 for the 16 variables evaluated, indicating excellent internal consistency reliability. The one-sample $t$-test results reveal that all the evolving competencies (B1-B16) are statistically significant. Table 4a presents the ranking, mean scores and standard deviation of the significance ratings for each competency. Overall, the mean scores range from 3.779 to 4.492 with the five most important evolving skills being communication and negotiation, ethics and professional conduct, value management, project management and life cycle cost analysis. The least significant evolving tasks include financial management, facilities management and quality assurance.

\section{[Please insert Tables $4 \mathrm{a}, 4 \mathrm{~b}$ and $4 \mathrm{c}$ here]}

The evolving competencies having significantly different perceptions between the respondent groups are information technology, communication and negotiation, soft skills, alternative disputes resolution (ADR) and ethics and professional conduct (see Table 4b). As QSs in developing countries remain tied to their traditional duties (Jaafar et al., 2016), some practitioners and students may lack an understanding of the evolving roles required. This further suggests disparities in the expected evolving competencies of QSs. Subsequently, the one-way ANOVA from summary data in Table $4 \mathrm{~b}$ manifests three distinctive groups (see Table $4 \mathrm{c})$.

\section{Discussion}

\section{The situation now}

In Table 3c, the two basic/core competencies with the highest mean scores are in Group 1, comprising 'valuation of works' and 'contract documentation'. An important contract administration role of consultant QSs is onsite measurement and valuation of work, which is part of the financial management of the supply chain (RICS, 2018). Post-contract work includes

\footnotetext{
This is the peer reviewed version of the following article: Yap, J. B. H., Skitmore, M., Lim, Y. W., Loo, S. C., \& Gray, J. (Accepted/In press). Assessing the expected current and future
} competencies of quantity surveyors in the Malaysian built environment. Engineering, Construction and Architectural Management. https://doi.org/10.1108/ECAM-01-2021-0091. This author accepted manuscript is deposited under a Creative Commons Attribution Non-commercial 4.0 International (CC BY-NC) licence. This means that anyone may distribute, adapt and build upon the work for non-commercial purposes, subject to full attribution. If you wish to use this manuscript for commercial purposes, please contact permissions@emerald.com. 
processing interim payment valuations as the work proceeds, the measurement and valuation of variation work, as well as preparation of final accounts (Cunningham, 2014). The QS has to report the growing construction costs and cash-flow status regularly to permit cost control activities to be carried out and retain the project budget. In investigating financial-related causes contributing to project delays in Malaysia, Abdul-Rahman et al. (2009) found that late interim valuation by the consultant $\mathrm{QS}$, inaccurate valuation of completed work and insufficient documentation/incomplete records for valuation are underlying causes of late payment. A comparable observation is also reported in Nigeria (Aibinu and Odeyinka, 2006). Against this background, timely and fair valuations are needed to avoid disputes between the contracting parties, cash flow problems and financial losses during project execution (Hiew and $\mathrm{Ng}, 2007$ ). QS is known as a profession in which its practitioners have been trained to have expert knowledge of contractual arrangements in the construction environment (Ashworth et al., 2013). Contract documentation is the ability of QS to prepare and interpret written information into a standard form that delivers the meaning of a particular project definitely. This competency covers the various forms of contract used in the construction industry and a thorough understanding of contract law and legislation (RICS, 2018). Any discrepancy in contract documentation can significantly undermine the time and cost control of construction projects (Olawale and Sun, 2010). The ambiguity of items, as well as errors and omissions in contract documentation, not only cause payment problems in contract execution but also necessitate rework in the form of correcting non-conforming work (Palaneeswaran et al., 2008; Ye et al., 2014). The adoption of digital engineering using BIM-based systems has gained momentum in recent years in the architecture, engineering and construction (AEC) industries but is still hampered by such challenges as poor awareness, high cost of implementation, inadequate technical know-how, low technology adoption, legal disputes and uncertainties in policies and concerns over data confidentiality (Li et al., 2019; Saka et al., 2020).

\footnotetext{
This is the peer reviewed version of the following article: Yap, J. B. H., Skitmore, M., Lim, Y. W., Loo, S. C., \& Gray, J. (Accepted/In press). Assessing the expected current and future competencies of quantity surveyors in the Malaysian built environment. Engineering, Construction and Architectural Management. https://doi.org/10.1108/ECAM-01-2021-0091. This author accepted manuscript is deposited under a Creative Commons Attribution Non-commercial 4.0 International (CC BY-NC) licence. This means that anyone may distribute, adapt, and build upon the work for non-commercial purposes, subject to full attribution. If you wish to use this manuscript for commercial purposes, please contact permissions@emerald.com.
} 
In Group 2, the leading basic/core competencies are 'professional practice' and 'construction law/regulation', both with mean scores of 4.558. Professional practice covers professionalism, which construes recognition of the significance of professional practice ethics, roles of professional associations and applicable legislation for practice in order to carry out the works effectively (Nkado and Meyer, 2001). The clients and consultants tend to perceive these skills as more important than do their counterparts in contractor and student. This competency is congruent with the RICS (2018) requirements, where QSs must be able to justify actions at all times and demonstrate a personal commitment to expectations of professional practice and abide the general principles of law and the legal system in the country of practice. QSs have a responsibility to uphold their professionalism when dealing with a conflict of interest and/or complaint, handling client's money and setting up professional indemnity insurance (RICS, 2018). According to Oosthuizen and Berry (2013), laws and legislation as a dimension of QS principals within a QS company constitutes two branches. The first branch refers to conventional laws according to the constitution of the country. The second branch refers to contract law. In this connection, competency relating to construction law and regulation is the knowledge of law, regulations and guidelines related to construction (Yogeshwaran et al., 2018). Nkado and Meyer (2001, p. 485), however, describe this as "awareness and understanding of, and ability to apply, relevant law". In Sri Lanka, Yogeshwaran et al. (2018) found a positive gap in this core competency among graduate QSs. Legal education is no longer exclusive to law students. A qualified QS graduate needs to be adequately trained to advise on all aspects of contract law and legislation (Maidin and Sulaiman, 2011). Being involved in advising clients, the QS is expected to have such relevant legal-related knowledge and skills as the current case-law of construction works, employment law, statutory compliance, consents and approvals (RICS, 2018).

\footnotetext{
This is the peer reviewed version of the following article: Yap, J. B. H., Skitmore, M., Lim, Y. W., Loo, S. C., \& Gray, J. (Accepted/In press). Assessing the expected current and future competencies of quantity surveyors in the Malaysian built environment. Engineering, Construction and Architectural Management. https://doi.org/10.1108/ECAM-01-2021-0091. This author accepted manuscript is deposited under a Creative Commons Attribution Non-commercial 4.0 International (CC BY-NC) licence. This means that anyone may distribute, adapt, and build upon the work for non-commercial purposes, subject to full attribution. If you wish to use this manuscript for commercial purposes, please contact permissions@emerald.com.
} 
The third most significant competency in this group is 'cost planning', which attained a consensus regardless of respondent types. Cost planning is critical for cost estimation from feasibility to design completion. The scope includes analysing design solution alternatives, cost control during the design phase, preparing cost appraisal reports and audit project scope (Yogeshwaran et al., 2018). This competency in design economics is needed throughout the pre-contract stage to understand how early-stage design decisions affect capital and operational costs (RICS, 2018). According to an interviewee in Caffieri et al.'s (2018) study of cost management of major capital projects, a cost consultant with considerable expertise and experience is required to provide strategic and reasoned advice over the accuracy and risks associated with cost, time, quality and buildability. On the other hand, inaccurate budgeting and systematically biased forecasts are detrimental to both contractors and clients (Lind and Brunes, 2015; Ling and Leong, 2002). As a corollary, decision-makers (e.g. planners, managers, investors, legislators) are ill-informed (Flyvbjerg et al., 2018). For example, Shehu et al. (2014, p. 1472) assert that "an overestimated cost will likely be unacceptable to the client at project feasibility stage, whereas an underestimated cost will typically lead to an increased outturn cost (ratio $>1.0$ )". According to Perera et al. (2007), cost planning is an essential competency for QSs as the technical appraiser in housing and development financing. The fourth competency here is 'measurement/quantification'. Quantification is the capability of QSs to define and measure construction works to value work and control costs at all stages of the construction process (RICS, 2018). An understanding of the rules and various categories of measurement is needed to quantify construction work in the production of pricing documents (Yogeshwaran et al., 2018). Dada and Jagboro's (2012) study of the expected technical skills of QSs in Nigeria found measurement/quantification competency to be perceived as less important than computer literacy and information technology skills, as this routine task is being automated by technology to improve accuracy and productivity. Against this background,

\footnotetext{
This is the peer reviewed version of the following article: Yap, J. B. H., Skitmore, M., Lim, Y. W., Loo, S. C., \& Gray, J. (Accepted/In press). Assessing the expected current and future competencies of quantity surveyors in the Malaysian built environment. Engineering, Construction and Architectural Management. https://doi.org/10.1108/ECAM-01-2021-0091. This author accepted manuscript is deposited under a Creative Commons Attribution Non-commercial 4.0 International (CC BY-NC) licence. This means that anyone may distribute, adapt, and build upon the work for non-commercial purposes, subject to full attribution. If you wish to use this manuscript for commercial purposes, please contact permissions@emerald.com.
} 
manual computation is time-consuming and error-prone where emerging Building Information Modelling (BIM) software (e.g. CostX, Cubicost) are now embedded with standard measurement methods to automate cost estimation process (Abanda et al., 2017). The other notable competency in this second group is 'personal and interpersonal skills', which are included as a mandatory element within RICS's competency framework (RICS, 2018). A would-be competency QS is expected to have is the ability to communicate effectively with others and acquire the 'soft' skills to be part of a team (Nkado and Meyer, 2001; Shafiei and Said, 2008). In investigating the skills for procurement management, Oke et al. (2018) categorise interpersonal skills as analytical operational skills. Undrrstanding the interpersonal dynamics of the team is a critical attribute for enhancing open communication (Yap, Leong, et al., 2020) and engendering effective teamwork (Adu and Opawole, 2019). Townsend et al. (2020, p. 04020101-6) note that "high-cooperation teams spend more time performing activities such as brainstorming, reviewing project progress, and receiving feedback, with less time spent resolving personality conflicts." Given that management-oriented competencies are becoming more important for future business success, these human-based skills should be included in QS academic and training curricula (Nkado, 2000).

Comparing Groups 3 and 4, it is unsurprising that contractor QS practitioners rated 'feasibility study' and 'business management' much lower than did their client and consultant peers, as well as the students. Given that feasibility and project analysis are undertaken in the very early stage of a project to make a Go/No-Go decision, these scopes are closely related to the client and consultant (Famiyeh et al., 2017; Samarghandi et al., 2016). Feasibility study requires an end-to-end understanding of project parameters, business goals and risk factors. The benefits associated with the projects are also estimated and scrutinised. Business administration is an emerging basic/core competency required of QSs in the future in view of the growing needs of clients, as it supports teamwork, leadership, communication and

\footnotetext{
This is the peer reviewed version of the following article: Yap, J. B. H., Skitmore, M., Lim, Y. W., Loo, S. C., \& Gray, J. (Accepted/In press). Assessing the expected current and future competencies of quantity surveyors in the Malaysian built environment. Engineering, Construction and Architectural Management. https://doi.org/10.1108/ECAM-01-2021-0091. This author accepted manuscript is deposited under a Creative Commons Attribution Non-commercial 4.0 International (CC BY-NC) licence. This means that anyone may distribute, adapt, and build upon the work for non-commercial purposes, subject to full attribution. If you wish to use this manuscript for commercial purposes, please contact permissions@emerald.com.
} 
presentation skills, and client care (Yogeshwaran et al., 2018). In this vein, business management plays a vital role in organising, analysing and planning various types of business operations in order to attain objectives and justify the existence of the organisation (Oosthuizen and Berry, 2013). QSs are now expected to be familiar with general economic and accounting principles like budgeting and cash flows (Dada and Jagboro, 2012; Shafiei and Said, 2008).

\section{The situation for the future}

The future success of QSs relies heavily on their adaptability and willingness to evolve with the increasing expectations of clients and changing business environments (Chandramohan et al., 2020; Cunningham, 2014). QSs are required to deal with numerous meticulous matters, such as measurement, valuation and financial scrutiny, while working in teams (Jaafar et al., 2016). In Table 4c, the top evolving competency is 'communication and negotiation'. Despite being equipped with technical knowledge, QSs have to communicate effectively and be good at dealing with people (Dada and Jagboro, 2012). For there to be efficient teamwork, communication has to be at its best (Yap, Leong, et al., 2020). Negotiation is a regular part of a surveyor's work (RICS, 2018). This skill is particularly useful for client and consultant QSs in solving conflicts and problems, deriving agreements and seeking commercial gain by negotiating discounts or seeking competitive prices from contractors/suppliers. For example, issue-focused conflict can easily be resolved when both parties agree to find a fair and satisfying resolution through negotiations (Creasy and Anantatmula, 2013). According to Hiew and Ng (2007), QSs should learn and apply effective negotiation skills, as opposed to confrontational debates, in settling variations and contractual claims. In this regard, negotiation involves a systematic approach to obtaining a satisfactory conclusion (RICS, 2018).

Behaving ethically is at the heart of what it means to be a professional and is rated the second most important evolving competency. Surveying is a professional practice having its

\footnotetext{
This is the peer reviewed version of the following article: Yap, J. B. H., Skitmore, M., Lim, Y. W., Loo, S. C., \& Gray, J. (Accepted/In press). Assessing the expected current and future competencies of quantity surveyors in the Malaysian built environment. Engineering, Construction and Architectural Management. https://doi.org/10.1108/ECAM-01-2021-0091. This author accepted manuscript is deposited under a Creative Commons Attribution Non-commercial 4.0 International (CC BY-NC) licence. This means that anyone may distribute, adapt, and build upon the work for non-commercial purposes, subject to full attribution. If you wish to use this manuscript for commercial purposes, please contact permissions@emerald.com.
} 
regulations, rules of conduct and ethical code upheld by established professional bodies and learned societies to enhance assurance and project clients against substandard practices (Oosthuizen and Berry, 2013; RICS, 2018). According to Nkado and Meyer (2001), professional practice is associated with the recognition of the profession's significance, ethics of professional practice, role of the professional associations and applicable legislation for practice. Intriguingly, the contractor practitioners tend to perceive the requirements of ethical thinking as less significant than do their client and consultant counterparts. The construction industry is highly susceptible to various forms of corrupt practices such as bribery, nepotism, kickbacks and collusion (Yap, Lee, et al., 2020). The potential to engage in corruption can be explained using 'fraud triangle' theory, which comprises of three elements of opportunities (forms of corruption), pressure for corruption and rationale for corruption (Bowen et al., 2012). In Hong Kong, Fan et al. (2002) found a difference in the perception of ethical standards within professional QSs. Professional norms are learned through active involvement and experience of progressing from junior to senior ranks, and thus there may be a process of ethical concept development. Professional practice curricula for professional education and continuing professional development courses should include ethical training to improve ethical compliances when facing ethical dilemmas during practice (Bowen et al., 2015; Ho and Ng, 2003).

Given that the construction industry is complex, fragmented and dynamic, and involves many parties often in adversarial relationships, disputes are almost inevitable (Alaloul et al., 2019). QSs should be able to carry out conflict avoidance, conflict management and dispute resolution through dispute resolution procedures (Chamikara et al., 2020; Chong et al., 2012; Fadhlin and Ismail, 2007). Such alternative dispute resolution (ADR) techniques as arbitration, adjudication, mediation, dispute review board and mini-trial have gained popularity in construction (Lee et al., 2016). QSs have to collect all relevant data, analyse status reports and

\footnotetext{
This is the peer reviewed version of the following article: Yap, J. B. H., Skitmore, M., Lim, Y. W., Loo, S. C., \& Gray, J. (Accepted/In press). Assessing the expected current and future competencies of quantity surveyors in the Malaysian built environment. Engineering, Construction and Architectural Management. https://doi.org/10.1108/ECAM-01-2021-0091. This author accepted manuscript is deposited under a Creative Commons Attribution Non-commercial 4.0 International (CC BY-NC) licence. This means that anyone may distribute, adapt, and build upon the work for non-commercial purposes, subject to full attribution. If you wish to use this manuscript for commercial purposes, please contact permissions@emerald.com.
} 
evaluate best or worse case scenarios. At the same time, disputing parties have separate and combined meetings with arbitrators or mediators, with QSs negotiating the most beneficial result on behalf of the client or becoming the legal representative of the disputing parties. Therefore, QSs need to understand the nature of proceedings and be able to negotiate the running costs involved. According to Amoatey et al. (2015), litigation is often caused by an absence of ADR clauses in the contract or a prolonged ADR process, as clients are becoming more demanding and discerning while less willing to accept risks without adequate recompense. Litigation, being the traditional dispute resolution method, is the costliest and, once the litigation process is started, the case is assessed by a judge or jury who may have little knowledge about construction work processes (Alaloul et al., 2019). With proactive contracting processes, the aim of incorporating ADR is to avoid costly formal proceedings. Nonetheless, disputes need to be addressed by prevention in the early stage of the project planning, with well-defined project particulars - such as scope, timeline and specification - to avoid ambiguity (Alaloul et al., 2019).

Soft skills refer to both the character traits and interpersonal skills that influence how well a person can work or interact with others (Shafie et al., 2014) - a people-related competency that makes a considerable difference to project effectiveness and efficiency (Potts, 2000). The term 'soft skills' covers a wide range of skills as diverse as teamwork, time management, empathy and delegation. Apart from technical-related knowledge, soft skills are needed for QSs to perform their work in a competent manner to deliver desired results (Shafiei and Said, 2008). In appraising how soft skills can influence project management success in the Vietnamese construction industry, for instance, Zuo et al. (2018) measure soft skills in six dimension, namely: communication, leadership, conflict management, achievement motivation, teamwork and cognitive. Using a structural equation modelling approach, all dimensions are found to be positively associated, with the strongest link being conflict

\footnotetext{
This is the peer reviewed version of the following article: Yap, J. B. H., Skitmore, M., Lim, Y. W., Loo, S. C., \& Gray, J. (Accepted/In press). Assessing the expected current and future competencies of quantity surveyors in the Malaysian built environment. Engineering, Construction and Architectural Management. https://doi.org/10.1108/ECAM-01-2021-0091. This author accepted manuscript is deposited under a Creative Commons Attribution Non-commercial 4.0 International (CC BY-NC) licence. This means that anyone may distribute, adapt, and build upon the work for non-commercial purposes, subject to full attribution. If you wish to use this manuscript for commercial purposes, please contact permissions@emerald.com.
} 
management, followed by teamwork and achievement motivation. With the emerging developments of technology, one of the threats faced by QSs is the lack of soft skills and attitudes (Yogeshwaran et al., 2018). In appraising the employers' expectations of soft skills to be possessed by QS graduates in Malaysia, Shafie et al. (2014) found a significant competency gap in the areas of (i) critical thinking, problem-solving and decision making skills, (ii) communication and language skills and (iii) capacity to work independently. Against this backdrop, QS practitioners and higher learning institutions need to work collaboratively to devise strategies to overcome existing weaknesses.

Computer literacy and construction information technology (IT) skills are expected play a major role in the activities of the QSs in the future (Ashworth et al., 2013; RICS, 2020). These involve the understanding and use of up-to-date information and communication systems, basic and specialist software and the Internet (Nkado and Meyer, 2001). The conventional working methods of cost estimation have been manual, time-consuming and error-prone (Abanda et al., 2017). Inefficiencies arise from the heavy reliance on the exchange of paper-based documents among the professionals involved. Against this background, Building Information Modelling (BIM)-based cost estimation software such as CostX and Cubicost can be exploited to automate the cost estimation process and improve accuracy. As Fung et al. (2014) highlight, the major challenges to the application of BIM in QS practice are lack of awareness about the capabilities of BIM and resistance to change. In this light, Henderson and Ruikar (2010, p. 309) emphasise that "technology implementation within construction organisations is not so much a technological problem as it is a human behavioural one". The other notable barriers include lack of BIM knowledge/proper skills, shortage of BIM professionals, poor vendor support, lack of government regulation about BIM, high initial cost and fixation to existing practices using 2D CAD-based drawings (Farooq et al., 2020; Hafez and Wong, 2014). In developing countries, the adoption rate of BIM is at $11 \%$ in Pakistan, for example (Farooq et al., 2020).

\footnotetext{
This is the peer reviewed version of the following article: Yap, J. B. H., Skitmore, M., Lim, Y. W., Loo, S. C., \& Gray, J. (Accepted/In press). Assessing the expected current and future competencies of quantity surveyors in the Malaysian built environment. Engineering, Construction and Architectural Management. https://doi.org/10.1108/ECAM-01-2021-0091. This author accepted manuscript is deposited under a Creative Commons Attribution Non-commercial 4.0 International (CC BY-NC) licence. This means that anyone may distribute, adapt, and build upon the work for non-commercial purposes, subject to full attribution. If you wish to use this manuscript for commercial purposes, please contact permissions@emerald.com.
} 
This is unsurprising, as the current construction IT proficiency level is still below industry needs (Yogeshwaran et al., 2018). To capitalise on this sophisticated software, QSs will need to possess considerable IT skills (Yogeshwaran et al., 2018) and be cognisant of BIM applications and its benefits through education and training (Hafez and Wong, 2014). Accepting changes in technology is important in moving forward. As such, QS firms need technology implementation strategies to overcome the barriers of "fear of uncertainty" and "the resistance to change".

\section{Concluding remarks}

This research investigated the competency requirements for quantity surveyors (QSs) in discharging and managing their professional duties within the construction and infrastructure (ECI) industry. Client demands are quickly increasing and becoming more sophisticated. To remain competitive, the contemporary roles of the QS profession need to evolve in changing business environments. Based on the meta-analysis of the literature, 12 basic/core and 16 evolving competencies were identified. A survey questionnaire was designed as the primary data collection instrument to solicit viewpoints from practising QSs working in contractor's, consultant's and client's organisations, as well as students in the QS programmes in higher education institutions (HEIs) in Malaysia. The data were then analysed using both descriptive and inferential statistics.

The first objective was to identify and appraise the basic/core competency requirements of QSs in the Malaysian built environment. The one-sample $t$-test revealed that all the 12 basic/core competencies identified are perceived to be significant. Overall, the five most important of these are cost planning, valuation of works, measurement/quantification, contract documentation and personal/interpersonal skills (Table 3a). Notably, there are expectations gaps in business management, feasibility study and general procurement advice, as these were

\footnotetext{
This is the peer reviewed version of the following article: Yap, J. B. H., Skitmore, M., Lim, Y. W., Loo, S. C., \& Gray, J. (Accepted/In press). Assessing the expected current and future competencies of quantity surveyors in the Malaysian built environment. Engineering, Construction and Architectural Management. https://doi.org/10.1108/ECAM-01-2021-0091. This author accepted manuscript is deposited under a Creative Commons Attribution Non-commercial 4.0 International (CC BY-NC) licence. This means that anyone may distribute, adapt, and build upon the work for non-commercial purposes, subject to full attribution. If you wish to use this manuscript for commercial purposes, please contact permissions@emerald.com.
} 
rated the lowest. Nonetheless, these form the basic technical knowledge taught in QS education in HEIs (Yogeshwaran et al., 2018). Further statistical analysis using ANOVA/K-W tests reveal the mean scores to be significantly different between the respondent groups for the basic/core competencies of business management, contract documentation, construction technology, variation of works, feasibility study, professional practice and construction law/regulation (Table 3b). It can be seen, therefore, that both client and consultant QSs have comparable opinions on the needed skills to perform mandatory tasks, while their contractor counterparts have differing perceptions. This is due to their different roles, where a consultant QS evaluates a client's needs and provides expert advice and opinion on what needs to be done, whereas a contractor QS ensures the project stays within the given budget and to maximise profit for their employer. The findings also reveal differing proficiency levels of competencies between client/consultant and contractor (Table 3c). The student group provides an appraisal on the course content of QS education programmes and expectations prior to gaining work experience.

The second objective was to examine the critical evolving skills to keep up with the changing market. Overall, the most sought-after skills are communication and negotiation, ethics and professional conduct, value management, project management and life cycle cost analysis (Table 4a). On the other hand, the least significant evolving competencies are financial auditing, facilities management and quality assurance. Further, the ANOVA/K-W tests found statistically significant differences for information technology, communication and negotiation, soft skills, alternative dispute resolution (ADR) and ethics and professional conduct (Table 4b). Again, the major disparity is between the client/consultant and contractor groups (Table 4c). The student group provided the revelation that some critical evolving competencies are at levels lower than industry expectations. This suggests a gap that currently exists in QS education in diverse skills outside the normal traditional QS skill requirements.

\footnotetext{
This is the peer reviewed version of the following article: Yap, J. B. H., Skitmore, M., Lim, Y. W., Loo, S. C., \& Gray, J. (Accepted/In press). Assessing the expected current and future competencies of quantity surveyors in the Malaysian built environment. Engineering, Construction and Architectural Management. https://doi.org/10.1108/ECAM-01-2021-0091. This author accepted manuscript is deposited under a Creative Commons Attribution Non-commercial 4.0 International (CC BY-NC) licence. This means that anyone may distribute, adapt, and build upon the work for non-commercial purposes, subject to full attribution. If you wish to use this manuscript for commercial purposes, please contact permissions@emerald.com.
} 
To remain relevant in the rapidly evolving landscape, the QS profession needs to recognise the vital competencies which are the key strengths for the present and future business success in the built environment. In creating extra values, QS practice is expanding rapidly by undertaking a wider spread of services. The evolving skills identified herewith have become the new criteria expected of a QS. In this vein, the role of training and education to transform and future-proof the professional development of QSs cannot be overemphasised in which the important basic/core and evolving competencies identified herewith should be given prominence. The QS education for the new generation must cater to industry needs. Professional bodies, councils and associations can guide curricula design, accreditation, assessment of professional competency and continuing professional development. Practising professionals must be committed to continuous learning to expand their skillset and help them adapt to change in the ever-changing business environments.

\section{References}

Abanda, F.H., Kamsu-Foguem, B. and Tah, J.H.M. (2017), "BIM - New rules of measurement ontology for construction cost estimation", Engineering Science and Technology, an International Journal, Vol. 20 No. 2, pp. 443-459.

Abdul-Rahman, H., Takim, R. and Min, W.S. (2009), "Financial-related causes contributing to project delays", Journal of Retail and Leisure Property, Vol. 8 No. 3, pp. 225-238.

Adesi, M., Owusu-Manu, D.G. and Murphy, R. (2018), "Strategic competences for pricing quantity surveying consultancy services", Engineering, Construction and Architectural Management, Vol. 25 No. 3, pp. 458-474.

Adu, E.T. and Opawole, A. (2019), “Assessment of performance of teamwork in construction projects delivery in South-Southern Nigeria", Journal of Engineering, Design and Technology, Vol. 18 No. 1, pp. $230-250$.

Aibinu, A.A. and Odeyinka, H.A. (2006), "Construction delays and their causative factors in Nigeria", Journal of Construction Engineering and Management, Vol. 132 No. 7, pp. 667-677.

Alaloul, W.S., Hasaniyah, M.W. and Tayeh, B.A. (2019), “A comprehensive review of disputes

\footnotetext{
This is the peer reviewed version of the following article: Yap, J. B. H., Skitmore, M., Lim, Y. W., Loo, S. C., \& Gray, J. (Accepted/In press). Assessing the expected current and future competencies of quantity surveyors in the Malaysian built environment. Engineering, Construction and Architectural Management. https://doi.org/10.1108/ECAM-01-2021-0091. This author accepted manuscript is deposited under a Creative Commons Attribution Non-commercial 4.0 International (CC BY-NC) licence. This means that anyone may distribute, adapt, and build upon the work for non-commercial purposes, subject to full attribution. If you wish to use this manuscript for commercial purposes, please contact permissions@emerald.com.
} 
prevention and resolution in construction projects", MATEC Web of Conferences, Vol. 270, p. 05012.

Amoatey, C. and Danquah, D. (2018), “Analysing project risks in Ghana's real estate industry", Journal of Facilities Management, Vol. 16 No. 4, pp. 413-428.

Amoatey, C.T., Ameyaw, Y.A., Adaku, E. and Famiyeh, S. (2015), "Analysing delay causes and effects in Ghanaian state housing construction projects", International Journal of Managing Projects in Business, Vol. 8 No. 1, pp. 198-214.

Ashworth, A., Hogg, K. and Higgs, C. (2013), Willis's Practice and Procedure for the Quantity Surveyor, 13th ed., Wiley-Blackwell, West Sussex, UK.

Bowen, P., Edwards, P. and Cattell, K. (2015), "Corruption in the South African construction industry: experiences of clients and construction professionals", International Journal of Project Organisation and Management, Vol. 7 No. 1, pp. 72-97.

Bowen, P.A., Edwards, P.J. and Cattell, K. (2012), "Corruption in the South African construction industry: A thematic analysis of verbatim comments from survey participants", Construction Management and Economics, Vol. 30 No. 10, pp. 885-901.

Buvik, M.P. and Rolfsen, M. (2015), "Prior ties and trust development in project teams - A case study from the construction industry", International Journal of Project Management, Vol. 33 No. 7, pp. $1484-1494$.

Caffieri, J.J., Love, P.E.D., Whyte, A. and Ahiaga-Dagbui, D.D. (2018), "Planning for production in construction: Controlling costs in major capital projects", Production Planning \& Control, Vol. 29 No. 1 , pp. $41-50$.

Cartlidge, D. (2018), New Aspects of Quantity Surveying Practice, 4th ed., Routledge, New York, NY.

Chamikara, P.B.S., Perera, B.A.K.S. and Rodrigo, M.N.N. (2020), “Competencies of the quantity surveyor in performing for sustainable construction", International Journal of Construction Management, Vol. 20 No. 3, pp. 237-251.

Chandramohan, A., Perera, B.A.K.S. and Dewagoda, K.G. (2020), "Diversification of professional quantity surveyors' roles in the construction industry: the skills and competencies required", International Journal of Construction Management, p. Latest article.

Chong, B.L., Lee, W.P. and Lim, C.C. (2012), "The roles of graduate quantity surveyors in the Malaysian construction industry", International Conference on Management and Education Innovation, IACSIT Press, Singapore.

Crafford, G. and Smallwood, J. (2007), “Clients' views on quantity surveying competencies”, Acta Structilia, Vol. 14 No. 1, pp. 33-55.

\footnotetext{
This is the peer reviewed version of the following article: Yap, J. B. H., Skitmore, M., Lim, Y. W., Loo, S. C., \& Gray, J. (Accepted/In press). Assessing the expected current and future competencies of quantity surveyors in the Malaysian built environment. Engineering, Construction and Architectural Management. https://doi.org/10.1108/ECAM-01-2021-0091. This author accepted manuscript is deposited under a Creative Commons Attribution Non-commercial 4.0 International (CC BY-NC) licence. This means that anyone may distribute, adapt, and build upon the work for non-commercial purposes, subject to full attribution. If you wish to use this manuscript for commercial purposes, please contact permissions@emerald.com.
} 
Creasy, T. and Anantatmula, V.S. (2013), "From every direction - how personality traits and dimensions of project managers can conceptually affect project success", Project Management Journal, Vol. 44 No. 6, pp. 36-51.

Cunningham, T. (2014), "The work and skills base of the quantity surveyor in Ireland - An introduction", available at:https://doi.org/10.21427/prwx-z232.

Dada, J.O. (2014), “A principal component analysis of skills and competencies required of quantity surveyors: Nigerian perspective", Organization, Technology and Management in Construction: An International Journal, Vol. 6 No. 2, pp. 1020-1032.

Dada, J.O. (2017), “An appraisal of paradigm shifts required of competence of the Nigerian quantity surveyors", Engineering, Construction and Architectural Management, Vol. 24 No. 6, pp. 1269-1280.

Dada, J.O. and Jagboro, G.O. (2012), “Core skills requirement and competencies expected of quantity surveyors: Perspectives from quantity surveyors, allied professionals and clients in Nigeria", Construction Economics and Building, Vol. 12 No. 4, pp. 78-90.

Dada, J.O. and Musa, N.A. (2016), "Key factors affecting the competence of quantity surveyors: Evidence from construction industry stakeholders in Nigeria", Journal of Engineering, Design and Technology, Vol. 14 No. 3, pp. 461-474.

Doloi, H. (2009), “Analysis of pre-qualification criteria in contractor selection and their impacts on project success", Construction Management and Economics, Vol. 27 No. 12, pp. 1245-1263.

Fadhlin, A. and Ismail, H. (2007), "Profile of the quantity surveying practice in Malaysia", International Conference on Construction Industry, Universitas Bung Hatta, Padang, Indonesia.

Famiyeh, S., Amoatey, C.T., Adaku, E. and Agbenohevi, C.S. (2017), "Major causes of construction time and cost overruns: A case of selected educational sector projects in Ghana", Journal of Engineering, Design and Technology, Vol. 15 No. 2, pp. 181-198.

Fan, L., Ho, C. and Ng, V. (2002), “A study of quantity surveyors' ethical behaviour”, Construction Management and Economics, Vol. 19 No. 1, pp. 19-36.

Farooq, U., Ur Rehman, S.K., Javed, M.F., Jameel, M., Aslam, F. and Alyousef, R. (2020), "Investigating BIM implementation barriers and issues in Pakistan using ISM approach", Applied Sciences, Vol. 10 No. 20, pp. 1-21.

Flyvbjerg, B., Ansar, A., Budzier, A., Buhl, S., Cantarelli, C., Garbuio, M., Glenting, C., et al. (2018), "Five things you should know about cost overrun", Transportation Research Part A: Policy and Practice, Vol. 118 No. December, pp. 174-190.

Hafez, S. and Wong, P.F. (2014), "Building Information Modeling application: focus-group discussion”, Građevinar, Vol. 66 No. 8, pp. 705-714.

\footnotetext{
This is the peer reviewed version of the following article: Yap, J. B. H., Skitmore, M., Lim, Y. W., Loo, S. C., \& Gray, J. (Accepted/In press). Assessing the expected current and future competencies of quantity surveyors in the Malaysian built environment. Engineering, Construction and Architectural Management. https://doi.org/10.1108/ECAM-01-2021-0091. This author accepted manuscript is deposited under a Creative Commons Attribution Non-commercial 4.0 International (CC BY-NC) licence. This means that anyone may distribute, adapt, and build upon the work for non-commercial purposes, subject to full attribution. If you wish to use this manuscript for commercial purposes, please contact permissions@emerald.com.
} 
Hair, J.F., Black, W.C., Babin, B.J. and Anderson, R.E. (2019), Multivariate Data Analysis, 8th ed., Cengage Learning, Hampshire, United Kingdom.

Henderson, J.R. and Ruikar, K. (2010), “Technology implementation strategies for construction organisations", Engineering, Construction and Architectural Management, Vol. 17 No. 3, pp. 309327.

Hiew, H. and Ng, P. (2007), "How the QS can create values in the procurement of construction works in Hong Kong”, Strategic Integration of Surveying Services, FIG Working Week, Hong Kong SAR, China, pp. 1-21.

Ho, M.F.C. and Ng, C.W.V. (2003), "Quantity surveyors' background and training, and their ethical concepts, conceptions and interests considerations", Construction Management and Economics, Vol. 21 No. 1, pp. 43-67.

Holmes, L. and Joyce, P. (1993), "Rescuing the useful concept of managerial competence: From outcomes back to process", Personnel Review, Vol. 22 No. 6, pp. 37-52.

Jaafar, M., Jalali, A. and Sini, N.M. (2016), “Assessing the duties and competencies of female quantity surveyors", Asian Social Science, Vol. 12 No. 1, pp. 129-137.

Kwofie, T.E., Botchway, E.A. and Amos-Abanyie, S. (2018), "Examining the performance level of project management competencies of architects in Ghana using gap analysis approach", Journal of Construction in Developing Countries, Vol. 23 No. 1, pp. 125-147.

Lee, C.K., Yiu, T.W. and Cheung, S.O. (2016), "Selection and use of Alternative Dispute Resolution (ADR) in construction projects - Past and future research", International Journal of Project Management, Vol. 34 No. 3, pp. 494-507.

Li, P., Zheng, S., Si, H. and Xu, K. (2019), "Critical challenges for BIM adoption in small and medium-sized enterprises: Evidence from China”, Advances in Civil Engineering, Vol. 2019, p. 9482350 .

Lind, H. and Brunes, F. (2015), "Explaining cost overruns in infrastructure projects: A new framework with applications to Sweden”, Construction Management and Economics, Vol. 33 No. 7, pp. $554-568$.

Ling, F. and Leong, E. (2002), "Performance of design-build projects in terms of cost, quality and time: Views of clients, architects and contractors in Singapore", Construction Economics and Building, Vol. 2 No. 1, pp. 37-46.

Lo, T.Y., Fung, I.W. and Tung, K.C. (2006), “Construction delays in Hong Kong civil engineering projects", Journal of Construction Engineering and Management, Vol. 132 No. 6, pp. 636-649. Maidin, A.J. and Sulaiman, S.S. (2011), "Importance of legal education for quantity surveying 
professionals: A proposal for developing a legal studies module for Malaysian system”, Journal of Applied Sciences Research, Vol. 7 No. 13, pp. 2249-2256.

Memon, M.A., Ting, H., Cheah, J.-H., Thurasamy, R., Chuah, F. and Cham, T.H. (2020), "Sample size for survey research: Review and recommendations", Journal of Applied Structural Equation Modeling, Vol. 4 No. 2, pp. i-xx.

Meyer, T. and Semark, P. (1996), "A framework for the use of competencies for achieving competitive advantage", South African Journal of Business Management, Vol. 27 No. 4, pp. 96-103.

Nkado, R. and Meyer, T. (2001), "Competencies of professional quantity surveyors: A South African perspective", Construction Management and Economics, Vol. 19 No. 5, pp. 481-491.

Nkado, R.N. (2000), "Competencies required by quantity surveyors in South Africa", in Akintoye, A. (Ed.), 16th Annual ARCOM Conference, Glasgow Caledonian University, Association of Researchers in Construction Management (ARCOM), Glasgow, UK.

Oke, A.E., Ogunsemi, D.R. and Adeyelu, M. (2019), "Quadrant and gap analysis of required and exhibited quantity surveyors' competencies", Journal of Engineering, Design and Technology, Vol. 17 No. 6, pp. 1161-1173.

Oke, A.E., Ogunsemi, D.R. and Adeyelu, M.F. (2018), "Quantity surveyors and skills required for procurement management", International Journal of Construction Management, Vol. 18 No. 6, pp. 507-516.

Oke, A.E. and Otasowie, K.O. (2020), "Gap analysis of mentoring practices in quantity surveying firms", International Journal of Construction Management, pp. 1-7.

Olanrewaju, A.L. (2016), "Measuring the service gaps in the roles of quantity surveyors in the emerging market", Benchmarking, Vol. 23 No. 5, pp. 1111-1131.

Olawale, Y.A. and Sun, M. (2010), "Cost and time control of construction projects: Inhibiting factors and mitigating measures in practice", Construction Management and Economics, Vol. 28 No. 5, pp. $509-526$.

Oosthuizen, P.M. and Berry, F.H. (2013), "Five maturity pillars of a quantity surveying company", International Journal of Project Organisation and Management, Vol. 5 No. 1-2, pp. 25-47.

Palaneeswaran, E., Love, P.E.D., Kumaraswamy, M.M. and Ng, T.S.T. (2008), "Mapping rework causes and effects using artificial neural networks", Building Research and Information, Vol. 36 No. 5 , pp. $450-465$.

Perera, B.A.K.S., Hemajith, S.D.M., Dilanthi, A. and Ginige, K.N. (2007), "Quantity surveyor as the technical appraiser in the Sri Lankan financial industry", Built Environment Education Conference, Universiti of Salford, Manchester, United Kingdom, pp. 1-12.

\footnotetext{
This is the peer reviewed version of the following article: Yap, J. B. H., Skitmore, M., Lim, Y. W., Loo, S. C., \& Gray, J. (Accepted/In press). Assessing the expected current and future competencies of quantity surveyors in the Malaysian built environment. Engineering, Construction and Architectural Management. https://doi.org/10.1108/ECAM-01-2021-0091. This author accepted manuscript is deposited under a Creative Commons Attribution Non-commercial 4.0 International (CC BY-NC) licence. This means that anyone may distribute, adapt, and build upon the work for non-commercial purposes, subject to full attribution. If you wish to use this manuscript for commercial purposes, please contact permissions@emerald.com.
} 
Perera, S., Pearson, J., Robson, S. and Ekundayo, D. (2011), “Alignment of academic and industrial development needs for quantity surveyors: the views of industry and academia”, RICS COBRA Research Conference, University of Salford, Manchester, United Kingdom.

Potts, K. (2000), "People and technology balance. Getting it right for large projects", Engineering Management Journal, Vol. 10 No. 2, pp. 61-64.

Project Management Institute. (2017), A Guide to the Project Management Body of Knowledge (PMBOK Guide), 6th ed., Project Management Institute, Inc, Newtown Square, Pennsylvania, USA. Ramdav, T. and Harinarain, N. (2020), "A strategic framework for the survival of the quantity surveying profession", Journal of Engineering, Design and Technology, Vol. 18 No. 6, pp. 14871518.

RICS. (2018), Pathway Guide: Quantity Surveying and Construction, London, UK, available at: https://www.rics.org/globalassets/rics-website/media/qualify/pathway-guides/quantity-surveyingconstruction-pathway-guide-chartered-rics.pdf.

RICS. (2020), The Futures Report 2020, London, UK, available at: https://www.rics.org/globalassets/rics-website/media/news/news--opinion/rics-future-report-2.pdf.

Saka, A.B., Chan, D.W.M. and Siu, F.M.F. (2020), "Drivers of sustainable adoption of building information modelling (BIM) in the Nigerian construction small and medium-sized enterprises (SMEs)”, Sustainability, Vol. 12 No. 9, p. 3710.

Samarghandi, H., Tabatabaei, S.M.M., Taabayan, P., Hashemi, A.M. and Willoughby, K. (2016), "Studying the reasons for delay and cost overrun in construction projects: The case of Iran", Journal of Construction in Developing Countries, Vol. 21 No. 1, pp. 51-84.

Shafie, H., Syed Khuzzan, S.M. and Mohyin, N.A. (2014), "Soft skills competencies of quantity surveying graduates in Malaysia: Employers' views and expectations", International Journal of Built Environment and Sustainability, Vol. 1 No. 1, pp. 9-17.

Shafiei, M.M. and Said, I. (2008), "The competency requirements for quantity surveyors: Enhancing continuous professional development", Sri Lankan Journal of Human Resource Management, Vol. 2 No. 1, pp. 17-27.

Shehu, Z., Endut, I.R., Akintoye, A. and Holt, G.D. (2014), "Cost overrun in the Malaysian construction industry projects: A deeper insight”, International Journal of Project Management, Vol. 32 No. 8, pp. 1471-1480.

Sonson, S. and Kulatunga, U. (2014), "Quantity surveying role and environmental influence in Saint Lucia”, International Conference on Construction in a Changing World, CIB 2014 International Conference, Heritance Kandalama, Sri Lanka.

\footnotetext{
This is the peer reviewed version of the following article: Yap, J. B. H., Skitmore, M., Lim, Y. W., Loo, S. C., \& Gray, J. (Accepted/In press). Assessing the expected current and future competencies of quantity surveyors in the Malaysian built environment. Engineering, Construction and Architectural Management. https://doi.org/10.1108/ECAM-01-2021-0091. This author accepted manuscript is deposited under a Creative Commons Attribution Non-commercial 4.0 International (CC BY-NC) licence. This means that anyone may distribute, adapt, and build upon the work for non-commercial purposes, subject to full attribution. If you wish to use this manuscript for commercial purposes, please contact permissions@emerald.com.
} 
Toor, S.-R. and Ogunlana, S.O. (2008), "Critical COMs of success in large-scale construction projects: Evidence from Thailand construction industry", International Journal of Project Management, Vol. 26 No. 4, pp. 420-430.

Townsend, R., Asce, M., Gershon, M. and Ph, D. (2020), “Attaining successful construction project execution through personnel and communication", Journal of Construction Engineering and Management, Vol. 146 No. 9, p. 04020101.

Wao, J.O. (2016), "Predicting the future of quantity surveying in the construction industry", Journal of Construction Project Management and Innovation, Vol. 5 No. 2, pp. 1363-1374.

Wao, J.O. and Flood, I. (2016), "The role of quantity surveyors in the international construction arena”, International Journal of Construction Management, Vol. 16 No. 2, pp. 126-137.

Wong, P.F., Hafez, S. and Faizul, A.M.R. (2014), "Capability of building information modeling application in quantity surveying practice", Journal of Surveying, Construction and Property, Vol. 5 No. 1, pp. 1-13.

Yap, J.B.H., Lee, K.Y. and Skitmore, M. (2020), “Analysing the causes of corruption in the Malaysian construction industry", Journal of Engineering, Design and Technology, Vol. 18 No. 6, pp. $1823-1847$.

Yap, J.B.H., Leong, W.J. and Skitmore, M. (2020), “Capitalising teamwork for enhancing project delivery and management in construction: Empirical study in Malaysia”, Engineering, Construction and Architectural Management, Vol. 27 No. 7, pp. 1479-1503.

Yap, J.B.H. and Skitmore, M. (2018), "Investigating design changes in Malaysian building projects", Architectural Engineering and Design Management, Vol. 14 No. 3, pp. 218-238.

Ye, G., Jin, Z., Xia, B. and Skitmore, M. (2014), “Analyzing causes for reworks in construction projects in China", Journal of Management in Engineering, Vol. 31 No. 6, p. 04014097.

Yogeshwaran, G., Perera, B.A.K.S. and Ariyachandra, M.R.M.F. (2018), “Competencies expected of graduate quantity surveyors working in developing countries", Journal of Financial Management of Property and Construction, Vol. 23 No. 2, pp. 202-220.

Zuo, J., Zhao, X., Nguyen, Q.B.M., Ma, T. and Gao, S. (2018), "Soft skills of construction project management professionals and project success factors: A structural equation model”, Engineering, Construction and Architectural Management, Vol. 25 No. 3, pp. 425-442.

Table 1. Identification of competencies required by quantity surveyors

\footnotetext{
This is the peer reviewed version of the following article: Yap, J. B. H., Skitmore, M., Lim, Y. W., Loo, S. C., \& Gray, J. (Accepted/In press). Assessing the expected current and future competencies of quantity surveyors in the Malaysian built environment. Engineering, Construction and Architectural Management. https://doi.org/10.1108/ECAM-01-2021-0091. This author accepted manuscript is deposited under a Creative Commons Attribution Non-commercial 4.0 International (CC BY-NC) licence. This means that anyone may distribute, adapt, and build upon the work for non-commercial purposes, subject to full attribution. If you wish to use this manuscript for commercial purposes, please contact permissions@emerald.com.
} 


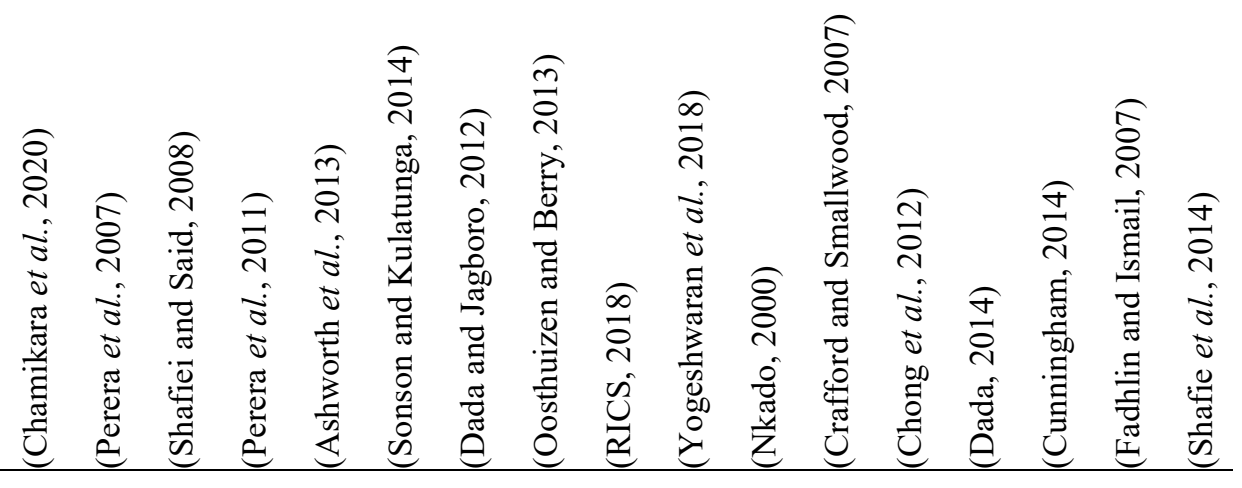

\begin{tabular}{|c|c|c|c|c|c|c|c|c|c|c|c|c|c|c|c|c|c|c|}
\hline$A$ & Basic/core & & & & & & & & ل & & & & & & $\sqrt{ }$ & & & \\
\hline $\begin{array}{l}\mathrm{A} \\
\mathrm{A}\end{array}$ & $\begin{array}{l}\text { Business } \\
\text { Contract }\end{array}$ & & $\begin{array}{l}v \\
\sqrt{ }\end{array}$ & $\begin{array}{l}v \\
\sqrt{ }\end{array}$ & $\begin{array}{l}v \\
\sqrt{ }\end{array}$ & $\begin{array}{l}v \\
\sqrt{ }\end{array}$ & $\begin{array}{l}v \\
\sqrt{ }\end{array}$ & $\begin{array}{l}v \\
\sqrt{ }\end{array}$ & $v$ & $\begin{array}{l}v \\
\sqrt{ }\end{array}$ & $\begin{array}{l}v \\
\sqrt{ }\end{array}$ & $\sqrt{ }$ & $\begin{array}{l}v \\
\sqrt{ }\end{array}$ & $\sqrt{ }$ & $v$ & $\sqrt{ }$ & $\sqrt{ }$ & $\sqrt{ }$ \\
\hline A & Construction & $\sqrt{ }$ & $\sqrt{ }$ & $\sqrt{ }$ & $\sqrt{ }$ & & $\sqrt{ }$ & $\sqrt{ }$ & & $\sqrt{ }$ & $\sqrt{ }$ & $\sqrt{ }$ & $\sqrt{ }$ & & & $\sqrt{ }$ & & \\
\hline A & Valuation of & $\sqrt{ }$ & & & & & & $\sqrt{ }$ & & $\sqrt{ }$ & & & $\sqrt{ }$ & & & $\sqrt{ }$ & $\sqrt{ }$ & $\sqrt{ }$ \\
\hline A & Personal/interp & $\sqrt{ }$ & & $\sqrt{ }$ & & & & $\sqrt{ }$ & $\sqrt{ }$ & $\sqrt{ }$ & & $\sqrt{ }$ & $\sqrt{ }$ & & & & & \\
\hline A & Cost planning & $\sqrt{ }$ & & $\sqrt{ }$ & $\sqrt{ }$ & $\sqrt{ }$ & $\sqrt{ }$ & $\sqrt{ }$ & & $\sqrt{ }$ & $\sqrt{ }$ & $\sqrt{ }$ & & $\sqrt{ }$ & $\sqrt{ }$ & $\sqrt{ }$ & $\sqrt{ }$ & $\sqrt{ }$ \\
\hline A & Financial & $\sqrt{ }$ & & & $\sqrt{ }$ & $\sqrt{ }$ & $\sqrt{ }$ & $\sqrt{ }$ & $\sqrt{ }$ & $\sqrt{ }$ & $\sqrt{ }$ & $\sqrt{ }$ & $\sqrt{ }$ & $\sqrt{ }$ & & $\sqrt{ }$ & & \\
\hline A & General & $\sqrt{ }$ & & $\sqrt{ }$ & $\sqrt{ }$ & $\sqrt{ }$ & & $\sqrt{ }$ & $\sqrt{ }$ & $\sqrt{ }$ & $\sqrt{ }$ & $\sqrt{ }$ & $\sqrt{ }$ & $\sqrt{ }$ & & $\sqrt{ }$ & $\sqrt{ }$ & \\
\hline A & Feasibility & & & & $\sqrt{ }$ & & & & & & & $\sqrt{ }$ & & $\sqrt{ }$ & $\sqrt{ }$ & & & $\sqrt{ }$ \\
\hline A & Professional & & & & & & & & & & & & $\sqrt{ }$ & $\sqrt{ }$ & & & & \\
\hline A & Measurement/q & $\sqrt{ }$ & & $\sqrt{ }$ & $\sqrt{ }$ & & & & & $\sqrt{ }$ & & & $\sqrt{ }$ & $\sqrt{ }$ & & & $\sqrt{ }$ & $\sqrt{ }$ \\
\hline A & Construction & & & & $\sqrt{ }$ & & & & $\sqrt{ }$ & $\sqrt{ }$ & & $\sqrt{ }$ & $\sqrt{ }$ & & & & & \\
\hline
\end{tabular}

This is the peer reviewed version of the following article: Yap, J. B. H., Skitmore, M., Lim, Y. W., Loo, S. C., \& Gray, J. (Accepted/In press). Assessing the expected current and future competencies of quantity surveyors in the Malaysian built environment. Engineering, Construction and Architectural Management. https://doi.org/10.1108/ECAM-01-2021-0091.

This author accepted manuscript is deposited under a Creative Commons Attribution Non-commercial 4.0 International (CC BY-NC) licence. This means that anyone may distribute, adapt, and build upon the work for non-commercial purposes, subject to full attribution. If you wish to use this manuscript for commercial purposes, please contact permissions@emerald.com. 
Table 1. Identification of competencies required by quantity surveyors (continued)

\begin{tabular}{|c|c|c|c|c|c|c|c|c|c|c|c|c|c|c|c|c|c|c|}
\hline$B$ & Evolving skills & & & & & & & & & & & & & & & & & \\
\hline B1 & Life cycle cost analysis & & $\sqrt{ }$ & $\sqrt{ }$ & & $\sqrt{ }$ & $\sqrt{ }$ & $\sqrt{ }$ & & & $\sqrt{ }$ & & & $\sqrt{ }$ & & $\sqrt{ }$ & $\sqrt{ }$ & \\
\hline B2 & Strategic planning & & $\sqrt{ }$ & & & $\sqrt{ }$ & $\sqrt{ }$ & & $\sqrt{ }$ & & $\sqrt{ }$ & & & & & $\sqrt{ }$ & & \\
\hline B3 & Information technology & & $\sqrt{ }$ & & $\sqrt{ }$ & $\sqrt{ }$ & $\sqrt{ }$ & & & $\sqrt{ }$ & $\sqrt{ }$ & $\sqrt{ }$ & $\sqrt{ }$ & & $\sqrt{ }$ & & & \\
\hline B4 & Quality assurance & $\sqrt{ }$ & $\sqrt{ }$ & & $\sqrt{ }$ & & & & $\sqrt{ }$ & $\sqrt{ }$ & $\sqrt{ }$ & & $\sqrt{ }$ & $\sqrt{ }$ & & $\sqrt{ }$ & $\sqrt{ }$ & \\
\hline B5 & Financial auditing & & & $\sqrt{ }$ & $\sqrt{ }$ & $\sqrt{ }$ & & & & & $\sqrt{ }$ & & & $\sqrt{ }$ & & $\sqrt{ }$ & & \\
\hline B6 & Capital allowances & $\sqrt{ }$ & & $\sqrt{ }$ & $\sqrt{ }$ & & & & & $\sqrt{ }$ & $\sqrt{ }$ & & & & & $\sqrt{ }$ & & \\
\hline B7 & Communication & & & & $\sqrt{ }$ & & & & & $\sqrt{ }$ & $\sqrt{ }$ & & & & & $\sqrt{ }$ & $\sqrt{ }$ & $\sqrt{ }$ \\
\hline B8 & Health and safety & & & & $\sqrt{ }$ & & & & & $\sqrt{ }$ & $\sqrt{ }$ & & & & & $\sqrt{ }$ & & \\
\hline B9 & Soft skills & & & $\sqrt{ }$ & $\sqrt{ }$ & & & & & $\sqrt{ }$ & & $\sqrt{ }$ & $\sqrt{ }$ & & & & & $\sqrt{ }$ \\
\hline B10 & Sustainability advisor & $\sqrt{ }$ & & & $\sqrt{ }$ & $\sqrt{ }$ & $\sqrt{ }$ & & & $\sqrt{ }$ & $\sqrt{ }$ & & & & & $\sqrt{ }$ & & \\
\hline B11 & Alternative disputes resolution & $\sqrt{ }$ & & $\sqrt{ }$ & & & & & & $\sqrt{ }$ & $\sqrt{ }$ & $\sqrt{ }$ & $\sqrt{ }$ & $\sqrt{ }$ & & $\sqrt{ }$ & $\sqrt{ }$ & \\
\hline B12 & Risk management & $\sqrt{ }$ & & & & & & & & & $\sqrt{ }$ & & $\sqrt{ }$ & $\sqrt{ }$ & & $\sqrt{ }$ & $\sqrt{ }$ & \\
\hline B13 & Project management & $\sqrt{ }$ & & $\sqrt{ }$ & $\sqrt{ }$ & & & & & $\sqrt{ }$ & $\sqrt{ }$ & $\sqrt{ }$ & $\sqrt{ }$ & $\sqrt{ }$ & & $\sqrt{ }$ & $\sqrt{ }$ & \\
\hline B14 & Value management & & & & & & & & & & $\sqrt{ }$ & & $\sqrt{ }$ & $\sqrt{ }$ & & $\sqrt{ }$ & $\sqrt{ }$ & \\
\hline B15 & Facilities management & & & & & & & & & $\sqrt{ }$ & & $\sqrt{ }$ & $\sqrt{ }$ & $\sqrt{ }$ & & $\sqrt{ }$ & $\sqrt{ }$ & \\
\hline B16 & Ethics and professional & $\sqrt{ }$ & & & & & & & & $\sqrt{ }$ & $\sqrt{ }$ & & & & & & & $\sqrt{ }$ \\
\hline
\end{tabular}


Table 2. Demographic profile of respondents $(\mathrm{N}=122)$

\begin{tabular}{|c|c|c|c|c|c|}
\hline \multirow[b]{2}{*}{ Working experience } & \multicolumn{4}{|c|}{ Respondents group } & \multirow[b]{2}{*}{ Total } \\
\hline & Contractor & Consultant & Client & Student & \\
\hline $0-5$ years & 23 & 15 & 8 & - & 46 \\
\hline $6-10$ years & 5 & 5 & 8 & - & 18 \\
\hline $11-15$ years & 5 & 4 & 5 & - & 14 \\
\hline $16-20$ years & 2 & 1 & 2 & - & 5 \\
\hline 21 years and above & 2 & 3 & 1 & - & 6 \\
\hline Total & 37 & 28 & 24 & 33 & 122 \\
\hline
\end{tabular}

\footnotetext{
This is the peer reviewed version of the following article: Yap, J. B. H., Skitmore, M., Lim, Y. W., Loo, S. C., \& Gray, J. (Accepted/In press). Assessing the expected current and future
} competencies of quantity surveyors in the Malaysian built environment. Engineering, Construction and Architectural Management. https://doi.org/10.1108/ECAM-01-2021-0091.

This author accepted manuscript is deposited under a Creative Commons Attribution Non-commercial 4.0 International (CC BY-NC) licence. This means that anyone may distribute, adapt, 
Table 3a. Mean and standard deviation of basic/core competencies that are required by QSs

\begin{tabular}{|c|c|c|c|c|c|c|c|c|c|c|c|}
\hline \multirow[t]{2}{*}{ Code } & \multirow[t]{2}{*}{ Basic/core competency } & \multicolumn{2}{|c|}{ Contractor $(\mathrm{N}=37)$} & \multicolumn{2}{|c|}{ Consultant $(\mathrm{N}=28)$} & \multicolumn{2}{|c|}{ Client $(\mathrm{N}=24)$} & \multicolumn{2}{|c|}{ Student $(\mathrm{N}=33)$} & \multicolumn{2}{|c|}{ Overall $(N=122)$} \\
\hline & & Mean & SD & Mean & $\mathrm{SD}$ & Mean & SD & Mean & SD & Mean & $S D$ \\
\hline A1 & Business management & 3.297 & 1.077 & 3.679 & 0.905 & 4.042 & 0.908 & 3.424 & 1.062 & 3.566 & 1.028 \\
\hline A2 & Contract documentation & 4.297 & 1.127 & 4.643 & 0.621 & 4.833 & 0.482 & 4.242 & 1.045 & 4.467 & 0.911 \\
\hline A3 & Construction technology & 4.000 & 1.080 & 4.536 & 0.637 & 4.208 & 0.658 & 4.152 & 1.051 & 4.205 & 0.909 \\
\hline A4 & Valuation of works & 4.405 & 1.142 & 4.893 & 0.315 & 4.625 & 0.576 & 4.333 & 0.960 & 4.541 & 0.892 \\
\hline A5 & Personal/interpersonal skills & 4.162 & 1.041 & 4.321 & 0.772 & 4.708 & 0.690 & 4.152 & 1.001 & 4.303 & 0.917 \\
\hline A6 & Cost planning & 4.460 & 1.070 & 4.679 & 0.548 & 4.708 & 0.464 & 4.394 & 1.004 & 4.541 & 0.873 \\
\hline A7 & Financial management & 3.838 & 1.214 & 4.000 & 0.817 & 4.500 & 0.511 & 4.152 & 1.021 & 4.090 & 0.988 \\
\hline A8 & General procurement advice & 3.973 & 1.213 & 3.893 & 0.786 & 4.333 & 0.637 & 3.939 & 0.972 & 4.016 & 0.971 \\
\hline A9 & Feasibility study & 3.405 & 1.117 & 4.179 & 0.723 & 4.250 & 0.794 & 3.970 & 1.059 & 3.902 & 1.016 \\
\hline A10 & Professional practice & 4.108 & 0.966 & 4.464 & 0.693 & 4.667 & 0.482 & 4.030 & 1.034 & 4.279 & 0.884 \\
\hline A11 & Measurement/quantification & 4.297 & 1.051 & 4.643 & 0.621 & 4.708 & 0.690 & 4.333 & 0.998 & 4.467 & 0.911 \\
\hline \multirow[t]{3}{*}{ A12 } & Construction law/regulation & 3.649 & 1.184 & 4.536 & 0.576 & 4.583 & 0.881 & 3.879 & 1.075 & 4.098 & 1.024 \\
\hline & Mean & 3.991 & 0.380 & 4.372 & 0.365 & 4.514 & 0.248 & 4.083 & 0.265 & 4.206 & 0.944 \\
\hline & $S D$ & 1.107 & 0.074 & 0.668 & 0.154 & 0.648 & 0.154 & 1.024 & 0.037 & 0.280 & 0.055 \\
\hline
\end{tabular}


Table 3b. ANOVA/Kruskal-Wallis test of basic/core competencies

\begin{tabular}{|c|c|c|c|c|c|c|c|c|}
\hline \multirow[t]{2}{*}{ Code } & \multirow[t]{2}{*}{ Basic and core competency } & \multicolumn{3}{|c|}{ Group } & \multicolumn{2}{|c|}{$\begin{array}{c}\text { Homogeniety of } \\
\text { Variances }\end{array}$} & \multicolumn{2}{|c|}{ ANOVA/KW } \\
\hline & & Mean & SD & $\mathrm{N}$ & $\begin{array}{l}\text { Levene's } \\
\text { Statistic }\end{array}$ & Sig. & $\mathrm{F}$ & Sig. \\
\hline$A 1$ & Business management & 3.566 & 1.028 & 122 & 0.700 & 0.554 & 3.018 & $0.033 *$ \\
\hline A1a & (Client + Consultant + Student $)$ & 3.682 & 0.991 & 85 & & & & \\
\hline A1b & (Contractor) & 3.297 & 1.077 & 37 & & & & \\
\hline$A 2$ & Contract documentation & 4.467 & 0.911 & 122 & 4.150 & $0.008 * *$ & 10.192 & $0.017^{*}$ \\
\hline $\mathrm{A} 2 \mathrm{a}$ & (Client+Consultant) & 4.731 & 0.564 & 52 & & & & \\
\hline $\mathrm{A} 2 \mathrm{~b}$ & (Contractor+Student) & 4.271 & 1.062 & 70 & & & & \\
\hline$A 3$ & Construction technology & 4.205 & 0.909 & 122 & 1.089 & 0.357 & 1.948 & $0.013 *$ \\
\hline A3a & (Client + Consultant + Student $)$ & 4.294 & 0.814 & 85 & & & & \\
\hline $\mathrm{A} 3 \mathrm{~b}$ & (Contractor) & 4.000 & 1.080 & 37 & & & & \\
\hline$A 4$ & Valuation of works & 4.541 & 0.892 & 122 & 7.214 & $0.000 * *$ & 7.927 & $0.048^{*}$ \\
\hline $\mathrm{A} 4 \mathrm{a}$ & (Consultant) & 4.893 & 0.315 & 28 & & & & \\
\hline $\mathrm{A} 4 \mathrm{~b}$ & (Client + Contractor + Student $)$ & 4.436 & 0.979 & 94 & & & & \\
\hline A5 & Personal/interpersonal skills & 4.303 & 0.917 & 122 & 1.272 & 0.287 & 2.223 & 0.089 \\
\hline A6 & Cost planning & 4.541 & 0.873 & 122 & 3.814 & $0.012 *$ & 0.619 & 0.892 \\
\hline A7 & Financial management & 4.090 & 0.988 & 122 & 3.773 & $0.013^{*}$ & 5.795 & 0.122 \\
\hline A8 & General procurement advice & 4.016 & 0.971 & 122 & 1.184 & 0.319 & 1.101 & 0.352 \\
\hline$A 9$ & Feasibility study & 3.902 & 1.016 & 122 & 2.037 & 0.112 & 5.099 & $0.002 * *$ \\
\hline A9a & (Client + Consultant + Student $)$ & 4.118 & 0.892 & 85 & & & & \\
\hline A9b & (Contractor) & 3.405 & 1.117 & 37 & & & & \\
\hline A10 & Professional practice & 4.279 & 0.884 & 122 & 0.930 & 0.428 & 3.483 & $0.018^{*}$ \\
\hline A10a & (Client+Consultant) & 4.558 & 0.608 & 52 & & & & \\
\hline $\mathrm{A} 10 \mathrm{~b}$ & (Contractor+Student) & 4.071 & 0.997 & 70 & & & & \\
\hline A11 & Measurement/quantification & 4.467 & 0.911 & 122 & 3.016 & $0.033^{*}$ & 4.534 & 0.209 \\
\hline$A 12$ & Construction law/regulation & 4.098 & 1.024 & 122 & 3.375 & $0.021 *$ & 22.84 & $0.000 * *$ \\
\hline $\mathrm{A} 12 \mathrm{a}$ & (Client+Consultant) & 4.558 & 0.725 & 52 & & & & \\
\hline $\mathrm{A} 12 \mathrm{~b}$ & (Contractor+Student) & 3.757 & 1.083 & 70 & & & & \\
\hline
\end{tabular}

Notes: ** Correlation is significant at the 0.01 level. * Correlation is significant at the 0.05 level. 
Table 3c. Grouping of basic/core competencies

\begin{tabular}{llcccc}
\hline Code & Basic and core competency & \multicolumn{3}{c}{ Ranked } & Group \\
\cline { 3 - 4 } & & Mean & SD & N & \\
\hline A4a & Valuation of works (Consultant) & 4.893 & 0.315 & 28 & 1 \\
A2a & Contract documentation (Client+Consultant) & 4.731 & 0.564 & 52 & 1 \\
A10a & Professional practice (Client+Consultant) & 4.558 & 0.608 & 52 & 2 \\
A12a & Construction law/regulation (Client+Consultant) & 4.558 & 0.725 & 52 & 2 \\
A6 & Cost planning (all) & 4.541 & 0.873 & 122 & 2 \\
A11 & Measurement/quantification (All) & 4.467 & 0.911 & 122 & 2 \\
A4b & Valuation of works (Client+Contractor+Student) & 4.436 & 0.979 & 94 & 2 \\
A5 & Personal/interpersonal skills (All) & 4.303 & 0.917 & 122 & 2 \\
A3a & Construction technology (Client+Consultant+Student) & 4.294 & 0.814 & 85 & 2 \\
A2b & Contract documentation (Contractor+Student) & 4.271 & 1.062 & 70 & 2 \\
A9a & Feasibility study (Client+Consultant+Student) & 4.118 & 0.892 & 85 & 3 \\
A7 & Financial management (All) & 4.090 & 0.988 & 122 & 3 \\
A10b & Professional practice (Contractor+Student) & 4.071 & 0.997 & 70 & 3 \\
A8 & General procurement advice (All) & 4.016 & 0.971 & 122 & 3 \\
A3b & Construction technology (Contractor) & 4.000 & 1.080 & 37 & 3 \\
A12b & Construction law/regulation (Contractor+Student) & 3.757 & 1.083 & 70 & 3 \\
A1a & Business management (Client+Consultant+Student) & 3.682 & 0.991 & 85 & 3 \\
A9b & Feasibility study (Contractor) & 3.405 & 1.117 & 37 & 4 \\
A1b & Business management (Contractor) & 3.297 & 1.077 & 37 & 4 \\
\hline
\end{tabular}


Table 4a. Mean and standard deviation of evolving competencies that are required by QSs

\begin{tabular}{|c|c|c|c|c|c|c|c|}
\hline \multirow[t]{2}{*}{ Code } & \multirow[t]{2}{*}{ Evolving competency } & \multicolumn{2}{|c|}{ Contractor $(\mathrm{N}=37)$} & \multicolumn{2}{|c|}{ Consultant $(\mathrm{N}=28)$} & \multicolumn{2}{|c|}{$\begin{array}{c}\text { Client (developer) } \\
\qquad(\mathrm{N}=24)\end{array}$} \\
\hline & & Mean & SD & Mean & SD & Mean & SD \\
\hline B1 & Life cycle cost analysis & 3.946 & 0.911 & 3.893 & 0.994 & 4.417 & 0.717 \\
\hline B2 & Strategic planning & 3.676 & 1.002 & 3.786 & 0.876 & 4.208 & 0.658 \\
\hline B3 & Information technology & 3.730 & 1.146 & 4.107 & 1.031 & 4.458 & 0.884 \\
\hline B4 & Quality assurance & 3.622 & 0.982 & 3.857 & 0.803 & 4.125 & 0.900 \\
\hline B5 & Financial auditing & 3.541 & 1.216 & 3.786 & 0.957 & 3.917 & 0.881 \\
\hline B6 & Capital allowances & 3.784 & 1.031 & 3.857 & 0.970 & 4.333 & 0.868 \\
\hline B7 & Communication and negotiation & 4.243 & 0.925 & 4.679 & 0.612 & 4.750 & 0.532 \\
\hline B8 & Health and safety & 3.703 & 0.909 & 4.071 & 0.858 & 4.250 & 0.897 \\
\hline B9 & Soft skills & 3.703 & 1.024 & 4.250 & 0.928 & 4.458 & 0.833 \\
\hline B10 & Sustainability advisor & 3.676 & 1.002 & 4.000 & 0.667 & 3.958 & 0.806 \\
\hline B11 & Alternative disputes resolution (ADR) & 3.838 & 1.118 & 4.107 & 0.685 & 4.458 & 0.779 \\
\hline B12 & Risk management & 3.784 & 0.947 & 4.071 & 0.663 & 4.083 & 0.881 \\
\hline B13 & Project management & 3.973 & 1.013 & 4.357 & 0.870 & 4.333 & 0.817 \\
\hline B14 & Value management & 4.027 & 1.040 & 4.321 & 0.612 & 4.042 & 0.908 \\
\hline B15 & Facilities management & 3.703 & 0.996 & 3.893 & 0.832 & 3.792 & 0.977 \\
\hline B16 & Ethics and professional conduct & 4.243 & 0.925 & 4.607 & 0.737 & 4.667 & 0.868 \\
\hline & Mean & 3.824 & 1.012 & 4.103 & 0.818 & 4.266 & 0.825 \\
\hline & $S D$ & 0.202 & 0.084 & 0.267 & 0.136 & 0.261 & 0.107 \\
\hline
\end{tabular}

Table 4b. ANOVA/Kruskal-Wallis test of basic/core competencies

\begin{tabular}{|c|c|c|c|c|c|c|c|c|}
\hline \multirow[t]{2}{*}{$\begin{array}{l}\text { Cod } \\
\text { e }\end{array}$} & \multirow[t]{2}{*}{ Evolving competency } & \multicolumn{3}{|c|}{ Group } & \multicolumn{2}{|c|}{$\begin{array}{c}\text { Homogeniety of } \\
\text { Variances }\end{array}$} & \multicolumn{2}{|c|}{ ANOVA/KW } \\
\hline & & \multirow[t]{3}{*}{ Mean } & \multirow[t]{3}{*}{$\mathrm{SD}$} & \multirow[t]{3}{*}{$\mathrm{N}$} & Levene & Sig. & $\mathrm{F}$ & Sig. \\
\hline & & & & & Statisti & & & \\
\hline & & & & & $\mathrm{c}$ & & & \\
\hline B1 & Life cycle cost analysis & 4.033 & 0.935 & 122 & 0.146 & 0.932 & 1.744 & 0.162 \\
\hline B2 & Strategic planning & 3.869 & 0.890 & 122 & 1.357 & 0.259 & 1.889 & 0.135 \\
\hline \multirow[t]{2}{*}{ B3 } & \multirow[t]{2}{*}{ Information technology } & \multirow[t]{2}{*}{4.025} & \multirow[t]{2}{*}{1.000} & \multirow[t]{2}{*}{122} & \multirow[t]{2}{*}{4.388} & $0.006^{*}$ & \multirow[t]{2}{*}{2.795} & \multirow[t]{2}{*}{$0.043^{*}$} \\
\hline & & & & & & * & & \\
\hline B3a & (Client+Consultant) & 4.269 & 0.972 & 52 & & & & \\
\hline $\mathrm{B} 3 \mathrm{~b}$ & (Contractor+Student) & 3.843 & 0.987 & 70 & & & & \\
\hline B4 & Quality assurance & 3.853 & 0.906 & 122 & 1.070 & 0.365 & 1.590 & 0.195 \\
\hline \multirow[t]{2}{*}{ B5 } & \multirow[t]{2}{*}{ Financial auditing } & \multirow[t]{2}{*}{3.779} & \multirow[t]{2}{*}{0.975} & \multirow[t]{2}{*}{122} & \multirow[t]{2}{*}{5.931} & $0.001 *$ & \multirow[t]{2}{*}{1.201} & \multirow[t]{2}{*}{0.312} \\
\hline & & & & & & * & & \\
\hline B6 & Capital allowances & 3.910 & 0.945 & 122 & 0.784 & 0.505 & 2.095 & 0.105 \\
\hline B7 & Communication and negotiation & 4.492 & 0.763 & 122 & 2.650 & 0.052 & 3.011 & $0.033 *$ \\
\hline
\end{tabular}




\begin{tabular}{|c|c|c|c|c|c|c|c|c|}
\hline $\mathrm{B} 7 \mathrm{a}$ & (Client+Consultant) & 4.712 & 0.572 & 52 & & & & \\
\hline B7b & (Contractor+Student) & 4.329 & 0.847 & 70 & & & & \\
\hline B8 & Health and safety & 3.975 & 0.913 & 122 & 0.244 & 0.865 & 1.981 & 0.121 \\
\hline B9 & Soft skills & 4.033 & 0.953 & 122 & 0.955 & 0.416 & 4.027 & $0.009 * *$ \\
\hline B9a & (Client + Consultant $)$ & 4.346 & 0.883 & 52 & & & & \\
\hline B9b & (Contractor+Student) & 3.800 & 0.942 & 70 & & & & \\
\hline B10 & Sustainability advisor & 3.869 & 0.852 & 122 & 3.230 & $0.025^{*}$ & 0.966 & 0.411 \\
\hline B11 & Alternative disputes resolution ( $A D R$ ) & 4.008 & 0.958 & 122 & 4.216 & $\begin{array}{c}0.007 * \\
*\end{array}$ & 2.978 & $0.034 *$ \\
\hline $\begin{array}{l}\text { B11 } \\
\text { a }\end{array}$ & (Client) & 4.458 & 0.779 & 24 & & & & \\
\hline $\begin{array}{l}\text { B11 } \\
\text { b }\end{array}$ & (Contractor + Consultant + Student $)$ & 3.898 & 0.968 & 98 & & & & \\
\hline B12 & Risk management & 4.025 & 0.818 & 122 & 1.449 & 0.232 & 1.752 & 0.160 \\
\hline B13 & Project management & 4.205 & 0.918 & 122 & 0.100 & 0.960 & 1.227 & 0.303 \\
\hline B14 & Value management & 4.205 & 0.881 & 122 & 0.819 & 0.486 & 1.649 & 0.182 \\
\hline B15 & Facilities management & 3.795 & 0.881 & 122 & 1.210 & 0.309 & 0.254 & 0.859 \\
\hline B16 & Ethics and professional conduct & 4.459 & 0.825 & 122 & 1.021 & 0.386 & 8.073 & $0.045^{*}$ \\
\hline $\begin{array}{l}\text { B16 } \\
\text { a }\end{array}$ & (Client + Consultant + Student $)$ & 4.553 & 0.764 & 85 & & & & \\
\hline $\begin{array}{l}\text { B16 } \\
b\end{array}$ & (Contractor) & 4.243 & 0.925 & 37 & & & & \\
\hline
\end{tabular}

Notes: As Table 3b.

Table 4c. Grouping of evolving competencies

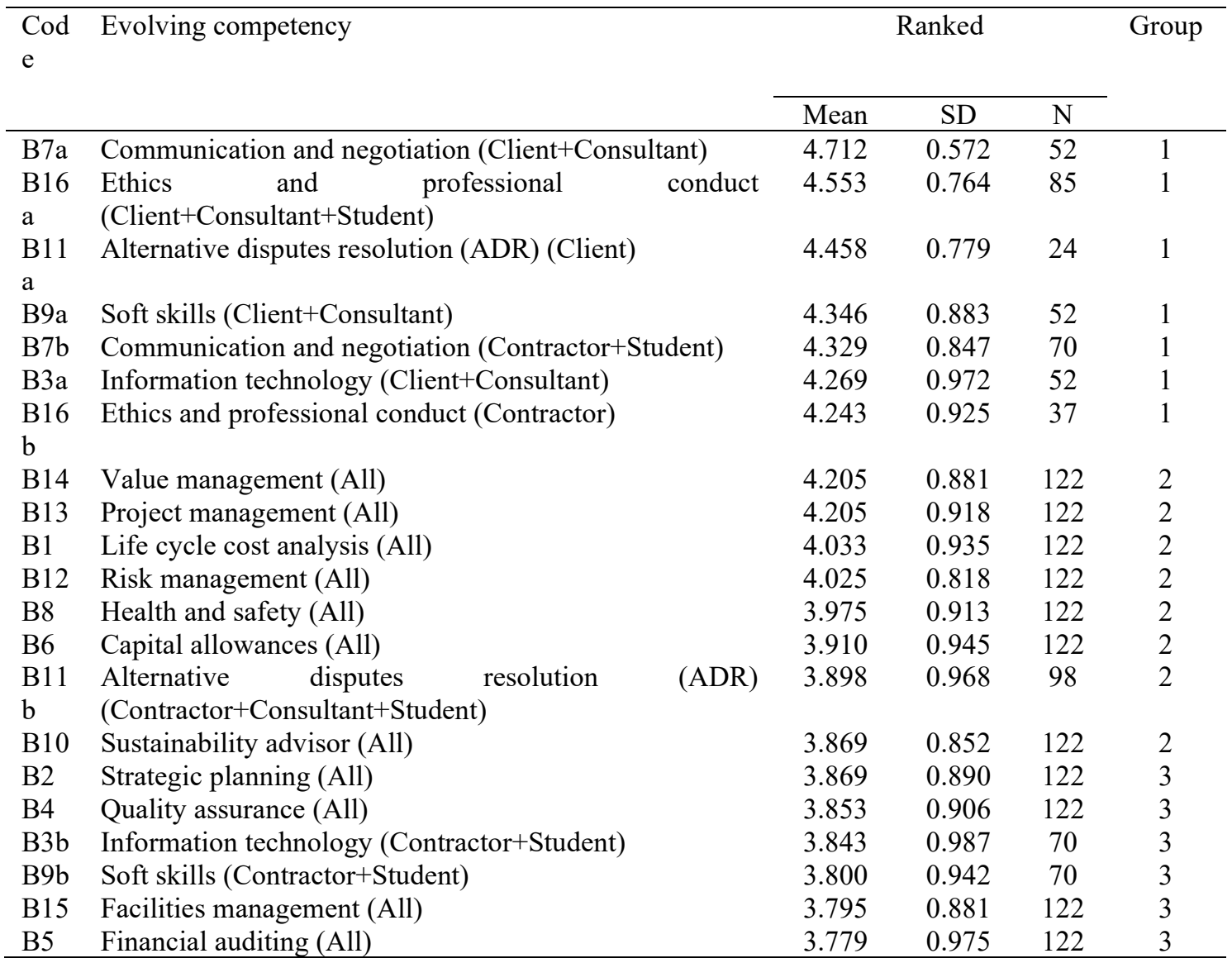


This is the peer reviewed version of the following article: Yap, J. B. H., Skitmore, M., Lim, Y. W., Loo, S. C., \& Gray, J. (Accepted/In press). Assessing the expected current and future competencies of quantity surveyors in the Malaysian built environment. Engineering, Construction and Architectural Management. https://doi.org/10.1108/ECAM-01-2021-0091. This author accepted manuscript is deposited under a Creative Commons Attribution Non-commercial 4.0 International (CC BY-NC) licence. This means that anyone may distribute, adapt, and build upon the work for non-commercial purposes, subject to full attribution. If you wish to use this manuscript for commercial purposes, please contact permissions@emerald.com. 